\title{
CHARACTERIZATION OF INSULIN-LIKE GROWTH FACTOR I (IGF-I) RECEPTORS OF HUMAN BREAST CANCER CELLS
}

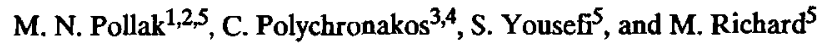 \\ Departments of ${ }^{1}$ Oncology, ${ }^{2}$ Medicipe, and ${ }^{3}$ Pediatrics, McGill University, \\ ${ }^{4}$ Polypeptide Hormone Laboratory of the Division of Endocrinology, and \\ ${ }^{5}$ Lady Davis Research Institute of the Jewish General Hospital, \\ 3755 Cote St Catherine Rd., Montreal, PQ, Canada H3T 1E2
}

Studies of binding of IGF-I to a plasma-membrane-enriched subcellular fraction prepared from MCF-7 buman breast cancer cells reveal the presence of 0.2 pmols specific binding sites for this mitogen per $\mathrm{mg}$ membrane protein, with an equilibrium affinity constant of $1.45 \mathrm{nM}^{-1}$. Competition studies with insulin, IGF-II, and an antiIGF-I receptor antibody are consistent with the presence of specific IGF-I receptors, and SDS-PAGE showed binding to a $130 \mathrm{kDa}$ subunit identical to that of receptors from human placenta. In addition, we show that IGF-I is more potent than estradiol and comparable to EGF in stimulating in vitro proliferation of MCF-7 cells, and that IGF-Istimulated proliferation of these cells is inhibited by a blocking monoclonal antibody against the IGF-I receptor. These results demonstrate that IGF-I is an important mitogen for MCF-7 cells and that the mitogenic effect is mediated by specific IGF-I receptors.

Recent studies suggest that the aberrant proliferative behaviour of neoplastic cells may be modulated by various peptide growth factors and inhibitors, which are either produced by the neoplastic cells themselves in an autocrine fashion, or by other cells. Earlier reports have described stimulatory effects of partially purified somatomedin preparations $(1,2)$ and of insulin $(3,4)$ on breast cancer cell lines, suggesting that these mitogens are involved in regulation of proliferation of breast cancer cells in vitro. We have recently reported the presence of specific binding sites for IGF-I on primary human neoplasms (5), and proposed that in vitro growth-stimulation studies may have clinical relevance. The autocrine production of IGF-I by breast cancer cell lines has been described by Huff et al (6).

Abbreviations: IGF-I, insulin-like growth factor I; IGF-II, insulin-like growth factor II; SDS-PAGE, sodium dodecyl sulfate polyacrylamide gel electrophoresis; EGF, epidermal growth factor; $E_{2}$, estradiol.

Correspondence to Dr. M. Pollak, Lady Davis Research Institute, 3755 Cote St Catherine Rd., Montreal, PQ, Canada H3T 1E2 
The insulin-like growth factors (somatomedins) are members of a family of polypeptide mitogens structurally related to proinsulin. IGF-I has been regarded as the principal mediator of growth hormone action, and is known to be produced by liver cells in response to growth hormone stimulation. More recent reports have demonstrated extrahepatic IGF-I synthesis, but less is known about the regulation of extra-hepatic production. Biological effects of IGF-I in vivo are related to local tissue concentration of the mitogen and various binding proteins, rather than simply being a function of circulating levels.

Binding of IGF-I to specific cell-surface receptors, which have been characterized in detail $(7,8)$ is the first step in the transduction of the mitogenic signal. As is the case for other peptide mitogen receptors, IGF-I receptors consist of an intracellular tyrosine kinase domain and an extracellular binding region. IGF-I binds to IGF-I receptors with higher affinity than to either insulin receptors or IGF-II receptors. Some studies suggest that mitogenic effects of IGF-II and insulin may be mediated, at least in certain tissues, by the binding of these peptides to IGF-I receptors $(9,10)$. The physiology of somatomedins has recently been reviewed (11).

In the present study, we characterize the IGF-I receptor of MCF-7 human breast cancer cells, compare it to receptors from non-neoplastic tissue, and describe the proliferative response to this mitogen.

\section{METHODS}

Cells and growth factors. MCF-7 cells (12) were kindly provided by Dr. R. Buick and K. Graham. Recombinant IGF-I was from Amgen, radiolabelled recombinant IGF-I from Amersham, and estradiol and recombinant insulin were from Sigma. Purified IGF-II was kindly provided by Drs. H. Guyda and B. Posner, and Alpha IR-3 antibody $(13,14)$ by Dr. Steven Jacobs.

Tissue Culture and membrane preparation. MCF-7 cells were routinely cultured in alpha medium supplemented with $10 \%$ FCS. A plasma membrane-enriched subcellular fraction was prepared from approximately $10^{9}$ cultured cells as previously described for primary tumours (5).

In vitro Cell growth. $3.5 \times 10^{3}$ cells were plated in $2 \mathrm{~cm}^{2}$ wells using phenol-red free alpha medium (PRFAM) with $10 \%$ charcoal-stripped fetal calf serum (CSFCS). After 48 hours, medium was changed to PRFAM with $1 \%$ CSFCS for 72 hours, and cells were cultured in the this medium, with or without supplemental EGF, IGF-I, or estradiol at various concentrations (but with identical concentrations of vehicles used for each factor) for 5 days, with daily media changes. Cell number was determined with a hemocytometer. Experiments were done in quadruplicate.

Thymidine incorporation. Cells were plated in $2 \mathrm{~cm}^{2}$ wells using similar attachment medium. After 48 hours, media was changed to PRFAM with $1 \%$ CSFCS for 72 hours, and cells were cultured in this medium, with or without supplemental IGF-I at various concentrations for 24 hours. Two hours prior to terminating the incubation, $1 \mathrm{microCi} / \mathrm{ml}$ tritiated thymidine was added to each well. After incubation, cells were washed in PBS, and then ruptured and precipitated in 10\% TCA. TCA-insoluble material was collected by centrifugation, and washed by repeat centrifugation in TCA. The final acid-insoluble pellet was dissolved in $\mathrm{NaOH}$, neutralized with $\mathrm{HCl}$, and radioactivity was determined using a liquid scintillation counter. Cell number was determined on replicate 
dishes, and rates of incorporation were calculated as dpm per cell per 2 hr and expressed as percentage of control values. Experiments were carried out in quadruplicate.

Binding Studies. Incubations and calculations were carried out using techniques similar to those previously described (5), except that incubations were carried out at 4 degrees $\mathrm{C}$ for 20 hours. The data illustrated is representative of three replicate experiments. Interexperiment variation of the equilibrium affinity constants and number of binding sites were each less than $10 \%$.

Gels. Electrophoresis of a receptor preparation was performed on a 3 - $7.5 \%$ polyacrylamide gradient gel after crosslinking with labelled IGF-I, solubilizing with $\mathrm{Na}$ dodecyl sulfate and reducing in $100 \mathrm{mM}$ dithiothreitol (15).

\section{RESULTS}

Under our experimental conditions, we observed $7.5 \%$ specific binding of IGF-I to a plasma membrane-euriched sub-cellular fraction of MCF-7 cells, as compared to $25 \%$ specific binding to a human placenta, a tissue known to have a particularly high concentration of IGF-I receptors (15). We carried out Scatchard analysis of the binding of IGF-I, and also performed competition studies using insulin, IGF-II, and a monoclonal antibody against the IGF-I receptor. Figure 1(a) illustrates competition of radiolabelled IGF-I with unlabelled IGF-I, insulin, and IGF-II for binding sites on the MCF-7 membranes, and figure 1 (b) is a Scatchard plot of the IGF-I binding data. Figure 2 illustrates competition of IGF-I with a blocking antibody against the human IGF-I receptor. The data are consistent with the presence of specific IGF-I receptors that bind IGF-I preferentially to insulin and IGF-II. Scatchard analysis using data from three replicate experiments showed an equilibrium affinity constant of $1.45 \pm 0.05 \mathrm{nM}^{-1}$ and binding sites for $0.2 \pm 0.02$ pmols IGF-I per mg membrane protein.

Electrophoresis (figure 3) showed labelled receptor mainly at a $130 \mathrm{kDa}$ band, in a position identical to that seen in a preparation of human placenta. This labelling was
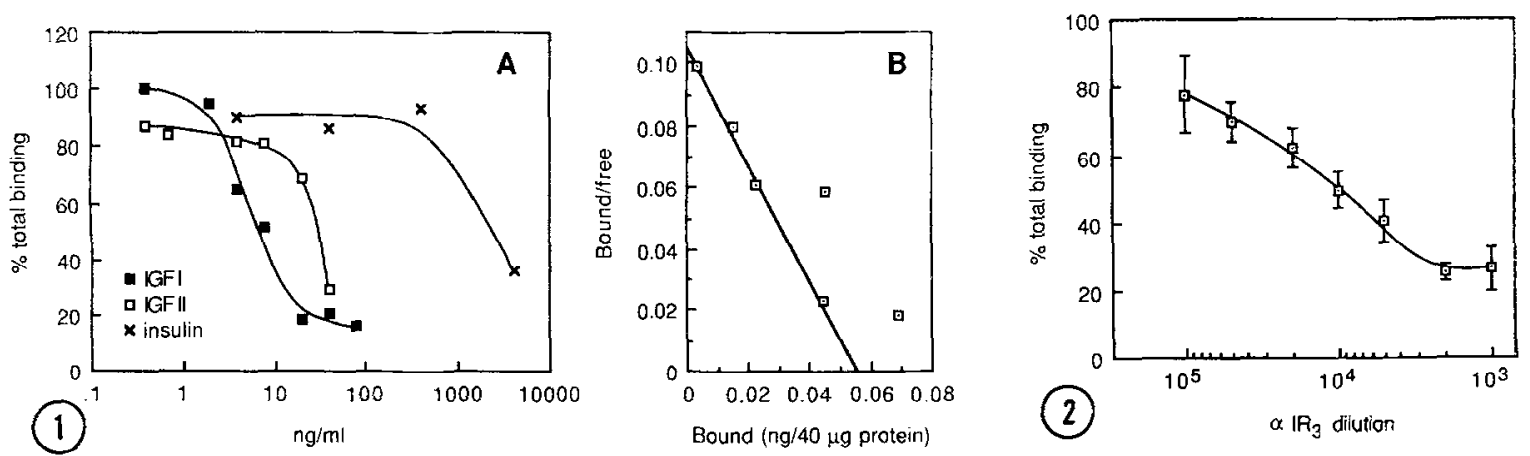

Figure 1. IGF-I binding to MCF-7 cell membranes. (A) Displacement of labelled IGF-I by unlabelled IGF-I, IGF-II, and insulin. (B) Scatchard plot of binding data for IGF-I. Experiments were performed as described in 'Methods'.

Figure 2. Displacement of labelled IGF-I from MCF-7 cell membranes by increasing concentrations of alpha IR3, a blocking antibody against the IGF-I receptor. Experiments were performed as described in 'Methods'. 


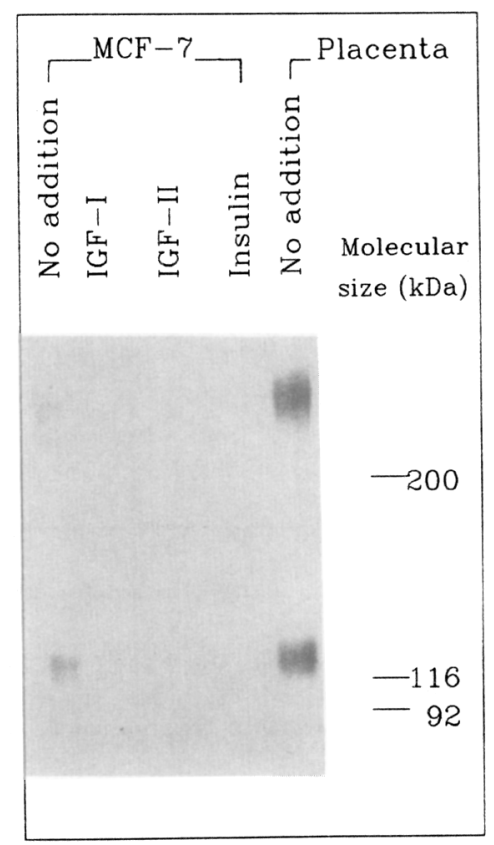

Figure 3. Affinity labelling of IGF-I receptors in MCF-7 membranes. Membranes were incubated with labelled IGF-I in the absence or presence of IGF-I $(300 \mathrm{ng} / \mathrm{ml})$, IGF-II $(150 \mathrm{ng} / \mathrm{ml})$, or insulin $(5000 \mathrm{ng} / \mathrm{ml})$, crosslinked and run on a $3-7.5 \%$ gradient gel in the presence of $2 \%$ SDS. The fifth lane shows a human placenta preparation for comparison.

totally abolished in the presence of excess IGF-I, IGF-II and insulin. $A$ small amount of labelling was observed at $260 \mathrm{kDa}$, but its total abolition by insulin indicates that it represents a subunit dimer rather than a type II IGF receptor.

We studied the mitogenic effect of IGF-I on MCF-7 cells under low-serum conditions, and compared it to that of estradiol and epidermal growth factor, using cell number as an endpoint. Each mitogen was used at concentrations maximally effective at stimulating proliferation in terms of increase in cell number at 5 days under experimental conditions used. As illustrated in figure 4 , IGF-I is a potent mitogen at nanomolar concentrations. This is consistent with a mitogenic effect mediated through the IGF-I receptor. A dose-response curve relating thymidine incorporation by MCF-7 cells to IGF-I concentration during a 24 hour exposure is shown in Figure 5 (a).

Alpha IR-3 is a monoclonal antibody against the IGF-I receptor that blocks binding of IGF-I to this receptor, but does not block the insulin or IGF-II receptors $(13,14)$. As shown in Figure 5(b), alpha IR-3 blocks the mitogenic effect of IGF-I, demonstrating that this mitogen acts through IGF-I receptors, rather than insulin receptors, in MCF-7 cells.

\section{DISCUSSION}

In this report, we demonstrate the presence of specific IGF-I receptors on MCF-7 human breast cancer cells, and show that these receptors are similar to previously 

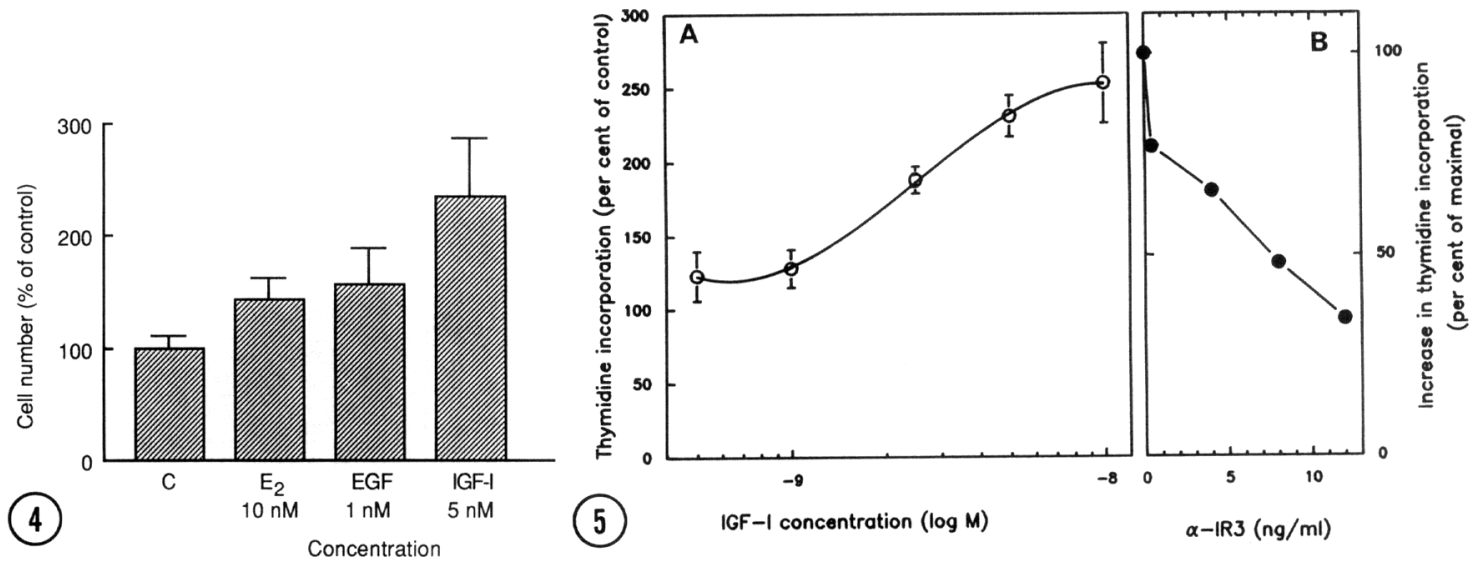

Figure 4. Mitogenic effect of IGF-I on MCF-7 cells. Optimum stimulatory concentrations of various mitogens for MCF-7 cells under the conditions described in 'Methods' were determined, and cell number was counted after cells were exposed to each mitogen for 5 days.

Figure 5. (A) Dose-response curve relating thymidine incorporation by MCF-7 cells to concentration of IGF-I in culture medium during a 24 hour iocubation. (B) Inhibition of IGF-I-stimulated proliferation of MCF-7 cells by a blocking antibody against human IGF-I receptors. Cells were incubatcd with or without $5 \times 10^{-9} \mathrm{M}$ IGF-I and the indicated dilution of the alpha IR-3 antibody, and thymidine uptake measured as described in Methods. Results are expressed as percentage of IGF-I induced increase in the absence of the antibody.

characterized IGF-I receptors from non-neoplastic tissues, at least in terms of affinity, compctitive binding characteristics, and electrophoretic mobility.

The potent mitogenic effect of IGF-I on MCF-7 cells at nanomolar concentrations and the blocking effect of alpha-IR3 are consistent with stimulation of proliferation through IGF-I receptors, rather than insulin or IGF-II receptors. A previous report (4) indicating that insulin is a mitogen for these cells noted a lack of correlation between insulin binding sites and mitogenic response. It is possible that some of the mitogenic effect of insulin seen in those studies was in fact mediated through IGF-I receptors rather than insulin receptors.

It has recently been shown that IGF-I is produced in an autocrine fashion by MCF-7 cells under certain conditions. The relative importance of autocrine-produced IGF-I versus exogenous IGF-I in the growth-stimulation of primary tumours is unknown, and may vary from tumour to tumour. It is interesting to note that Huff et el have shown that MDA-231 cells, which exhibit higher autocrine production of IGF-I than MCF-7 cells, exhibit higher baseline proliferation and less response to exogenous IGF-I than MCF-7 cells (6).

We previously detected IGF-I binding sites on primary human neoplasms, and proposed the possibility of therapeutic approaches based on depriving IGF-I receptor-positive tumour cells of mitogenic stimulation by somatomedins (5). The present report, together with a recent study showing that serum and estrogen-stimulated proliferation of MCF-7 
cells can be slowed by exposure of cells to an IGF-I receptor blocking antibody (16), provide additional justification for further studies in this area.

\section{ACKNOWLEDGMENTS}

This work was supported by a grant to MP from the Cancer Research Society of Montreal. We thank Dr. S. Jacobs for making available the alpha IR3 antibody. Correspondence to Dr. M. Pollak, Lady Davis Research Institute, 3755 Cote St Catherine Rd., Montreal, PQ, Canada H3T 1E2

\section{REFERENCES}

1. Furlanetto, R., Decarlo, J. (1984) Cancer Res. 44:2122-2128

2. Mayal, Y., Shiu, R., Bhaumick, B., Bala, M. (1984) Cancer Res. 44:5486-5490

3. Osborne, C.K., Bolan, G., Monaco, M.E., and Lippman, M.E. (1976) Proc. Nat. Acad. Sci. USA, 73: $4536-4540$

4. Osborne, C.K., Monaco, M.E., Lippman, M.E., and Kahn, C.R. (1978) Cancer Res., 38:94-102

5. Pollak, M.N., Perdue, J.F., Margolese, R.G., Baer, K. and Richard, M. (1987) Cancer Letters 38:223-230

6. Huff, K., Kaufman, D., Gabbay, K., Spencer, E., Lippman, M., Dickson, R. (1986) Cancer Res. 46:4613-4619

7. Sasaki,N., Rees-Jones, R., Zick, Y., Nissley, S. and Rechler, M. (1985) J. Biol. Chem. 260: $9793-9804$

8. Ulrich, A., Gray, A., Tam, A., Yang-Feng, T. Tsubokawa, M., Collins, C., Henzel, W., Lebon, T. et al. (1986) EMBO J. 5: 2503-2512

9. Flier, J., Usher, P. and Moses, A. (1986) . Proc. Natl. Acad. Sci. U.S.A. 83: 664-668

10. Van Wyk, J.J., Graves, D.C., Casella, S.J., Jacobs, S. (1985) J. Clin. Endocrinol. Metab. 61:639

11. Zapf,J., Froesch, E.R. (1986) Hormone Res. 24: 121-130

12. Graham, K.A., Trent, J.M., Osborne, C.K., McGrath, C.M., Minden, M.D., Buick, R.N. (1986) Breast Can. Res. Treat. 8(1): 29-34

13. Kull, F.C., Jacobs, S., Su, Y., Svoboda, M.E., Van Wyk, J.J. and Cuatrecasas, P. (1983) J. Biol. Chem. 258: 6561-6566

14. Jacobs, S., Cook, S., Svoboda, M., Van Wyk, J. (1986) Endocrinology 118:223-26

15. Massague, J and Czech, M. (1982) J. Biol. Chem. 257: 5038 - 5045

16. Rohlik, Q.T., Adams, D., Kull, F.C., Jacobs, S. (1987) Biochem. Biophys. Res. Comm. 149: $276-281$ 